\title{
Effects of Land Use Change on Banana Production: A Case Study of Imenti South Sub-County of Meru County in Kenya
}

\author{
Kevin A. Nyamamba ${ }^{1}$, Tom O. Ouna ${ }^{2}$, Hellen Kamiri ${ }^{3}$, Erwin Pane ${ }^{4}$ \\ 1,2Department of Humanities and Languages, Karatina University, Kenya \\ ${ }^{3}$ Department of Agricultural Sciences, Karatina University, Kenya \\ ${ }^{4}$ Agrotechnology Study Program, Faculty of Agriculture Universitas Medan Area, Medan, Indonesia \\ Email: kevinayiera89@gmail.com; erwinpane60@gmail.com
}

\begin{abstract}
:
Most high agricultural potential regions in Kenya such as Imenti South (Meru County) have exceeded their population density and have been associated with sharp decline in farm productivity. There has been a systematic transformation of land use for banana production in the area. This has led to reduction in land acreage under other crops and increase in land acreage under banana farming. This study focused on land use and banana production trends between the years 2000 to 2019 in Imenti South. To achieve the objective, the study used mixed research design that involved qualitative and quantitative approaches. A sample size of 377 respondents was identified using simple random sampling. Banana yields and land acreage data were obtained from Imenti South Agricultural office for the study period. The main research instruments were questionnaires for households and key informants. Majority of the respondents (72\%) in the study region admitted to have changed the land use and type of crops they have been farming during the study period whereas $28 \%$ changed from other crops to banana farming. Land acreage and banana production have been increasing during the study period in the area. The study revealed there is positive and statistically significant relationship $(r=.617 ; p=.004)$ between land under banana and production. The study recommends that stakeholders in County governments should establish departments that independently identify, analyses, monitor and educates the famers on the new technologies that improves and increases banana production
\end{abstract}

Keywords:

banana farming; land use; trends; land use change; small holder farmers

\section{Introduction}

Agriculture is the major occupational sector in many Sub-Saharan Africa (SSA) countries and a source of livelihood for the rural community (UNEP, 2011). Monish and Padmanabhan (2016) contend that East Africa has been subjected to a series of disturbances both natural and man-made, drought, and civil disturbances. Damage to the natural environment is a reflection of the disruption of the earth's lungs (forests) as a result of anthropocentric attitudes of humans who exploit excessively (Yusin \& Diani, 2020). Land use is the process of arranging the activities undertaken in a certain land cover type to produce, change or maintain it (Abere and Waithaka, 2014). The purpose of deliberate land-use changes is to increase local capacity of lands to support the human enterprise. Growth trends in banana production are evident in Africa's banana export which grew by $2.4 \%$ in 2012 as exports reached 649000 tonnes (FAO, 2018a). In Kenya banana is a popular food crop, with production of about 2 million tons annually from approximately 80,000 ha (MoA, 2013). Out of $582,636 \mathrm{Km}^{2}$ of available land in Kenya, about $17 \%$ supported by rain-fed agriculture, 2.2 $\%$ out of $17 \%$ is under forests reserve, while $80 \%$ is classified as arid and semi-arid. 
Banana production has become a popular enterprise in Kenya since the enactment of the Kenya Coffee Act (GOK, 2015c) section 4, which allowed small holder farmers to uproot coffee crops. The farmers had an opportunity of replacing coffee plants with banana crop coffee production Mt Kenya region (Karanja and Nyoro, 2002).

This change offered farmers with hope and freedom to diversify from coffee production to other crops especially bananas. Many coffee farmers shifted to banana production after long periods of low coffee returns, poor management of co-operative societies, rising cost of farm inputs and low yields (GOK, 2002). With the positive developments in banana production most of the small-scale farmers took up banana production but produce small, inconsistent quantities of varying quality (Splisbury et al., 2003).

Bananas farming have emerged as the major income earner and food item among the rural small holder's population of Kenya hence promoting Kenya's economic growth (GOK, 2011). Economic growth is a process of increasing the production capacity of an economy that is realized in the form of an increase in national and regional income (Suryani \& Rony, 2020).

In 2012 banana production constituted $38 \%$ of the total value of fruits produced in Kenya (GOK, 2012). Banana is one of the key economic enterprise in Mt. Kenya environs providing food and source of income to cater for health care, households school fees, procurement of food and home improvement (Mbaka et al., 2008, USAID, 2013). A study by Karienye \& Kamiri (2020), established that there has been an increase in acreage banana farm lands for the years 2009 to 2017, where it has been expanding gradually beginning 960 hectares in 2009 to 2910 hectares in 2017 Imenti South.

According to GOK (2012), the leading counties in banana production in Kenya are Meru (40\%), Kirinyaga (21\%), and Tharaka Nithi (19\%). Banana is a key livelihood source for Meru's population and is grown on $2.2 \%$ of the County's total agricultural land. In 2015, a total of 382,390 metric tonnes were produced earning the farmers approximately KES 3,700 million. It accounts for nearly half the annual total tonnage of fruits produced in Kenya (GOK, 2008).

Table 1. Banana Production Systems in Meru County Data

\begin{tabular}{|l|l|l|}
\hline Structure of Banana Production & Percentage (\%) & Land Size \\
\hline Large scale banana farmers & $1.8 \%$ & $>0.8$ hectares \\
\hline Medium scale farmers & $18.6 \%$ & $0.2-0.8$ hectares \\
\hline Small holder farmers & $79.6 \%$ & $<0.2$ hectares \\
\hline Total & 100 & \\
\hline
\end{tabular}

Source: Cyriaque et al. (2017) 


\subsection{Ecological Requirements for Planting Banana}

Morton, (1987) notes banana requires a warm and a humid climate, although it can do well from sea level up to an altitude of 1200 metres above the sea level. Consequently banana can be grown in temperature range of between $10^{\circ} \mathrm{C}$ and $40^{\circ} \mathrm{C}$, with higher productivity when temperatures are above $24^{\circ} \mathrm{C}$ for a considerable period. The crop requires longer period of time to mature in cooler regions. Low temperatures and humidity during active growth stage show reduced growth and yields. Banana has high water demand due to its vegetative nature, with approximately $25 \mathrm{~mm}$ per week being the minimum for optimum growth. An average annual rainfall of $1700 \mathrm{~mm}$, which is distributed well annually, is considered the most optimal. Drought, inadequate sun light and stagnant is dangerous and may cause diseases like Panama Wilt, hence low productivity (Nelson et al., 2006).

It is generally considered that fertility in soil is important for successful to banana farming, as the plant is a heavy feeder of soil the nutrients and water. Bananas are among the fruits which has limited root zone, thus soil depth and area drainage are key factors to consider when identifying soil suitability of banana growing. Soil suitability to grow the banana plants is between $0.5 \mathrm{~m}$ to I meter deep, well drained, rich in organic matter, fertile and a soil that retains moisture. This will result to healthy crop and banana fruit. Bananas grow well on alluvial and volcanic soils. A soil $\mathrm{pH}$ range of 5.5-7.5 is suitable for bananas plants, with a $\mathrm{pH}$ of 5.5 considered optimal (Macharia et al., 2010). A low pH however, leads to solubility of soil elements such as iron, aluminum, and manganese; these can be toxic and have negative effects on the plants like reduced root growth. This is exacerbated when the soil becomes water logged has low carbon levels.

A low $\mathrm{pH}$ also reduces the availability of other nutrients for example calcium. Careful fertilizer management reduces soil acidification. Soil $\mathrm{pH}=6.5$ can reduce the existence of elements such as boron, zinc, copper and iron. Ecological requirement is crucial to any farming activity to be successful; thus deep analysis and assessment before any farming.

\subsection{The Objective of the Study}

The objective this was to evaluate land use and banana production trends between the years 2000 to 2019, in South Imenti sub County.

\section{Research Methods}

\subsection{Location and Extent of the Study Area}

This study was conducted in Imenti South Sub-County of Meru County. It is on the lower side of Mount Kenya, on the windward side at an altitude ranging between $850 \mathrm{~m}$ and $2240 \mathrm{~m}$ above sea level. The sub county has six administrative wards: Abogeta East, Abogeta West, Igoji East, Igoji West, Nkuene and Mitunguu (Figure 1). The study covered Abogeta East and Mitunguu Wards which have high concentration of banana farms. These two wards are located between latitude $00^{\circ} \mathrm{N}$ and $05^{\circ} \mathrm{N}$ and longitude $35^{\circ} \mathrm{E}$ and $37^{\circ} \mathrm{E}$. 


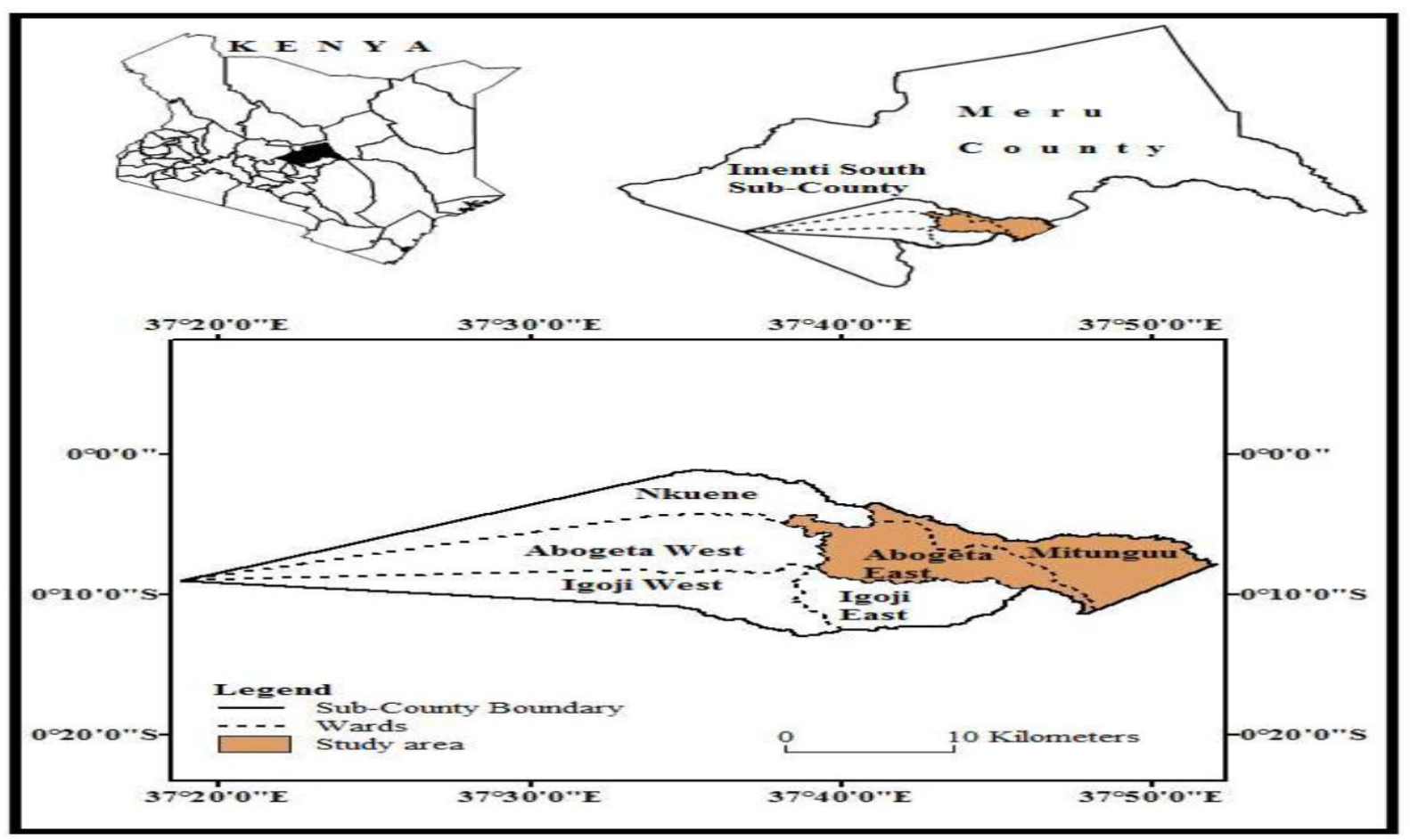

Figure 1. Map of the Study Area showing Imenti South Sub County and the sampled wards (Abogeta East and Mitunguu Wards)

Source: (Kenya Forest Service -GIS department, 2020)

\subsection{Climatic Conditions and Soils Characteristcics}

The study area experiences modified tropical climate of the Kenya highlands (GoK, 2008), with moderate amounts of rainfall and has temperatures ranging between $12.4^{\circ} \mathrm{C}$ and $24.5^{\circ} \mathrm{C}$.In the area, long rains are experienced from October to December and the short rains from March to May every year. The Imenti Sub-County experiences a bimodal rainfall pattern with average annual rainfall of between $800 \mathrm{~mm}$ and $2000 \mathrm{~mm}$ well distributed throughout the year. The soils are dark brown moderately fertile loam soils that are well drained, with the main economic activity in the study area being agriculture. These soils overlay hard volcanic lavas but are believed to have originated from volcanic ash. Where drainage is impeded, black cotton soils have developed with time (Schmidt et al., 2006).

\subsection{Relief, Drainage and Ecological Conditions}

The study area is well drained with permanent rivers where farmers get water for irrigation. The two main permanent rivers which supply water for irrigation in this study area are River Thingithu and Kithino (MoA, 2013). There are also several intermittent streams, swamps, boreholes and springs in the Lower Imenti Forest areas. The region slopes gently towards the north and the east. Meru County has varied ecological zones ranging from upper highlands, lower highlands, and upper midlands and lower midlands (Schmidt et al., 2006). The upper highlands zones covers majority of the county's area including Imenti South SubCounty. In these areas different types of economic activities are practiced, ranging from dairy farming, banana growing, tea farming and coffee growing. 


\subsection{Reseach Design}

The study adopted mixed research design to evaluate land use and banana production trends Imenti South Sub County. The study involved use of triangulation of methods whereby both qualitative and quantitative techniques were adopted to collect data using structured questionnaires that was administered to smallholder banana farmers; Focus Group Discussions (FGDs); in-depth interview to key informants; photographs analysis and direct observation of land use systems. Historical data on land acreage (ha) and banana production (in tonnes) were acquired from Imenti South Agricultural offices.

\section{a. Selection of Study Area and Sites}

The study area was purposively selected to include Abogeta and Mitunguu wards diverse locations where banana farming has been intensively grown from 2000 in Imenti South.

\section{b. Sample Size and Procedure}

Simple random sampling method was used to choose the respondents for the study. The target population for this study consisted of smallholder's banana farmers. According to GOK (2019) population statistics, the population of Imenti-South was approximately 205,487 of 64,186 households. The sample size was thus calculated following Krejcie and Morgan, (1970) as follows: $\mathrm{S}=\mathrm{X} 2 \mathrm{NP}(1-\mathrm{P}) \div \mathrm{d} 2(\mathrm{~N}-1)+\mathrm{X} 2 \mathrm{P}(1-\mathrm{P})$. Thus, a sample size of 377 respondents was obtained from a total population of 64, 186 households. Further to determine the sample size for the two wards, proportionate method was used and actual sample size per site attained as shown in Table 2. The respondents also included key informants such as agricultural extension officers. A total of $376(99.73 \%)$ questionnaires were fully filled and returned after the data collection.

\subsection{Data Collection}

\section{a. Methods and Procedures}

Primary and secondary data were collected and included individual interviews, (FGDs), data extraction from records and researcher direct observations. Quantitative and qualitative data collection methods and acquisition were used. Studies that combine the two methods are more inclusive than those that employ one type of methodology (Creswell and Plano, 2011).

Table 2. Tabulated Sample Size per Study Area Based on Number of Households, GOK (2019)

\begin{tabular}{|l|l|l|l|}
\hline Study location & Number of households & \% Proportion & Tabulated sample size \\
\hline Abogeta ward & 10,917 & 52.8 & 199 \\
\hline Mitunguu ward & 9,729 & 47.2 & 178 \\
\hline Total & 20,464 & 100 & 377 \\
\hline
\end{tabular}

1) Primary Methods

Quantitative methods included the use of surveys to collect data on land acreage and banana yields. Qualitative methods used in the study were interviews to key informants and FGDs. The researcher used direct observation to enhance primary data. FGDs sessions were conducted to confirm data from the households. The FGDs is advantageous over individual interviews as its saves time, money and offers an opportunity to collect diverse information on certain topic (Morgan, 1988).

\section{2) Secondary Sources}

Historical document analysis was used to examine production and land acreage data. Other sources of data included journal articles, government reports, Meru County strategic 
plans, County abstracts and books which gave background information on land acreage and production.

\section{b. Research Instruments}

The study used structured questionnaires to gather information from the smallholder banana farmersZ. In-depth interviews were conducted on key informants. Photographic images analysis and direct observations in the field were used to enforce collected data.

\subsection{Data Analysis}

Survey data from the questionnaires were cleaned, coded and entered in SPPS Version 21 (SPSS, 2012) for analysis. Quantitative data was analysed using descriptive statistics. Graphical methods such as charts, tables and graphs were used for data presentation.

\section{Result and Discussion}

The purpose of this study was to examine land use and banana production trends between the year 2000 to 2009 in Imenti South sub County.

\subsection{Land Use Trends in Imenti South Sub-County}

This section highlights the findings of data analysis on land acreage for banana production. Numerical and graphical measures, the analysis of land acreage was done for years 2000- 2019.

\section{a. Land Uses Changes between the Years 2000-2019}

Table 3. Land Uses Changes between the Years 2000-2019

\begin{tabular}{|c|c|c|c|}
\hline Years & $\begin{array}{l}\text { Type of Land } \\
\text { Use }\end{array}$ & Percentage & $\begin{array}{l}\text { Possible Reasons for Land Use } \\
\text { Change }\end{array}$ \\
\hline \multirow[t]{4}{*}{$2000-2004$} & Bananas & $15 \%$ & Dwindling financial returns \\
\hline & Coffee & $27 \%$ & Alternative source of income \\
\hline & Maize & $24 \%$ & Farm income needs \\
\hline & Others & $34 \%$ & Low productivity \\
\hline Total & & $100 \%$ & \\
\hline \multirow[t]{4}{*}{$2005-2009$} & Bananas & $19 \%$ & Emerging markets \\
\hline & Coffee & $18 \%$ & Low financial returns \\
\hline & Maize & $31 \%$ & Diminishing farm outputs \\
\hline & Others & $32 \%$ & Low productivity \\
\hline Total & & $100 \%$ & \\
\hline \multirow[t]{3}{*}{$2010-2014$} & Bananas & $64 \%$ & $\begin{array}{l}\text { Ready and reliable markets and } \\
\text { food security }\end{array}$ \\
\hline & Coffee & $16 \%$ & Low financial returns \\
\hline & Maize & $20 \%$ & $\begin{array}{l}\text { Diminishing farm outputs, high costs } \\
\text { of production, climate variability }\end{array}$ \\
\hline Total & & $100 \%$ & \\
\hline \multirow[t]{3}{*}{$2015-2019$} & Bananas & $83 \%$ & $\begin{array}{l}\text { Ready and reliable markets and } \\
\text { food security }\end{array}$ \\
\hline & Coffee & $5 \%$ & Low financial returns \\
\hline & Maize & $12 \%$ & $\begin{array}{l}\text { Diminishing farm outputs, high } \\
\text { costs of production, climate } \\
\text { variability }\end{array}$ \\
\hline Total & & $100 \%$ & \\
\hline
\end{tabular}


The study revealed that from the year 2000 to 2019, most small holder farmers reported an increase on land area under banana production. In the years 2000-2004, land under coffee was at $(27 \%)$, Maize $(24 \%)$ and bananas (15\%). Other crops took a $34 \%$. In the period 2005-2009, bananas acreage increased to $19 \%$ while coffee dropped to $18 \%$ while land under maize cultivation was at 31\%. Between the 2010 and 2014, bananas were (64\%) and maize (20\%). In the period 2015 to 2019 , land use under banana was at increased by $19 \%$ to reach $83 \%$. The growth trajectory was cited as a result of ready and reliable markets for banana produce, food security and lower cost of production. These findings agree with the report by Farmbiz Africa, (2019) that small holder farmers have adopted banana farming due to accessibility of markets and because bananas provide alternative sources of income. Maize production was reported by $24 \%$ of the respondents in the period 2000-2004 while 31\%, 2005-2009 and by 20\% in the period 2010-2014 which represented a 19\% reduction in the farmers growing maize. This was probably due to competition of land by other crops or possible lower production. Land use under coffee production was reported by $27 \%$ of the respondents in the 2000-2004 declining to 5\% for 2014 to 2019 . However, the reason for the decline of land use under coffee production was cited as low financial returns, Imenti South Banana Growers Association, (2019) also recognized that dwindling coffee prices since the 1980 s made farmers to uproot coffee trees when coffee prices started fluctuating and replaced them with banana farming. Some farmers shifted to banana farming and as it recorded higher profitability and productivity which eventually attracted many other farmers to start cultivating bananas. The results from this study indicated changes in land use from coffee farming to banana farming in Imenti South Sub-County.

Table 4. Summary of Analysis of Variance for Crop production (Banana, Coffee and Maize) in Imenti South sub-county

\begin{tabular}{llcccc}
\hline & Sum of Squares & Df & Mean Square & F & Sig. \\
\hline Between Groups & 81712175188.133 & 2 & 40856087594.067 & 7.711 & .001 \\
Within Groups & 302023719389.600 & 57 & 5298661743.677 & & \\
Total & $\mathbf{3 8 3 7 3 5 8 9 4 5 7 7 . 7 3 3}$ & $\mathbf{5 9}$ & & & \\
\hline
\end{tabular}

$*$ Significance is at .005

Table 3 reveals that there was a statistically significant difference between crops as demonstrated by one-way ANOVA $(F(2,57)=7.711, p=.001)$. This means that production of bananas, maize and coffee was significantly different over the period between the year 2000 and the year 2019 .

Table 5. Land Use Trends in Terms of Land Acreage under Banana, Coffee and Maize in Imenti South Sub-county (Post hoc test)

\begin{tabular}{|l|l|l|l|}
\hline (I) Type of crop & \multicolumn{1}{|c|}{ (J) Type of crop } & Mean Difference (I-J) & Sig. \\
\hline Bananas & Maize & $2849.500^{*}$ & .000 \\
Maize & Coffee & $1762.050^{*}$ & .009 \\
& Bananas & $-2849.500^{*}$ & .000 \\
coffee & Coffee & -1087.450 & .147 \\
& Bananas & $-1762.050^{*}$ & .009 \\
& Maize & 1087.450 & .147 \\
\hline
\end{tabular}

Further observation of the Tukey post hoc test presented in table 5 showed that land under bananas was statistically significantly larger than the land under maize $(p=.000)$. There was a statistically significant difference between land under coffee production and land under banana production $(p=.009)$. However, the difference between land allocated to maize production and land under coffee was not statistically different $(p=.147$.$) . From the data$ 
presented therefore, it is clear that land use trends for the past period of 20 years in Imenti south sub county has been in favour of banana production.

\section{b. Land Acreage under Banana Crop from the Year 2000 to 2019}

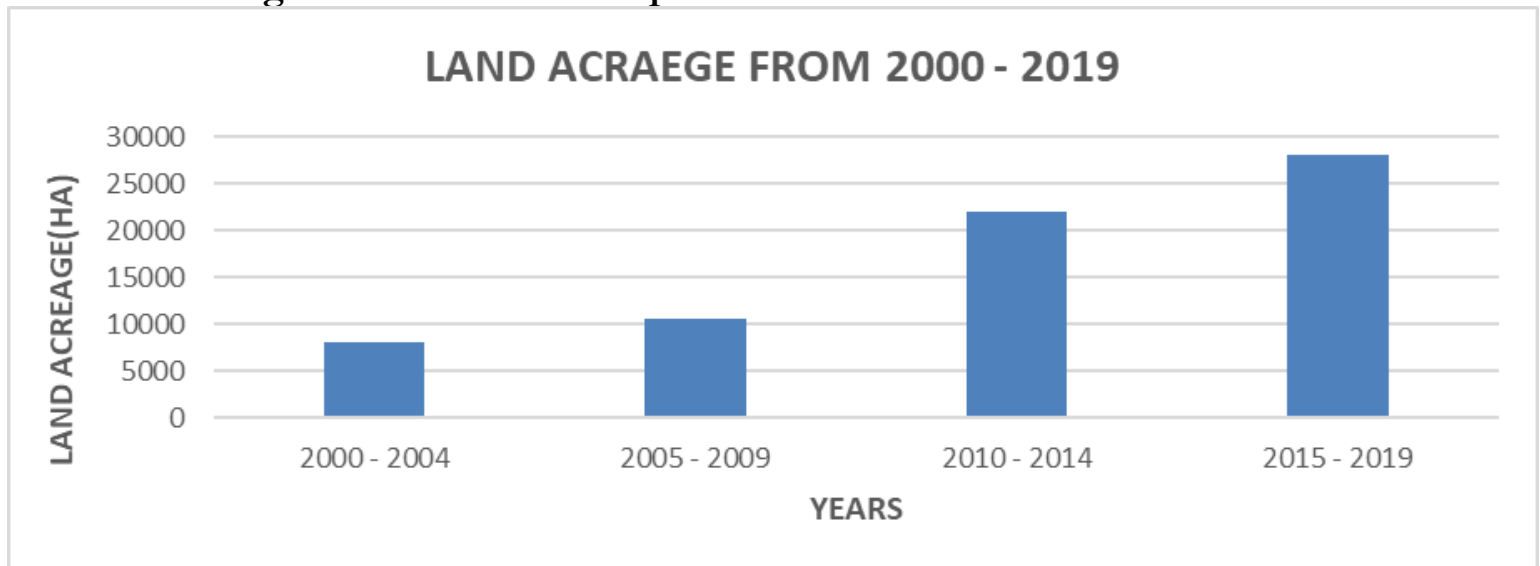

Figure 2. Land Acreage under Bananas (Imenti South Sub-County Agricultural Office, 2019)

From 2000 to 2004 the land under bananas was 8080 hectares, 2005 - 2009 increased to 10488 while between 2010-2014 lands under bananas was 21949 and 2015-2019 was 28121 in Imenti South Sub-County. The study findings also revealed that land area under banana production increased during the period 2000 to 2019 as farmers opted to convert most of their crop land to banana growing. Data obtained from Imenti South Sub-County agricultural office indicated that farmers have changed land use and type of crops they have been farming in the last 20 years with the highest change observed in the period 2015 to 2019 at $40.97 \%$. This concurs with GOK (2014) which found that some households in Meru County had changed crops grown.

Over a period of time, land use towards banana production has been associated with improved living standards as banana offers higher returns as opposed to the crops which were grown previously in the study area. Consequently, banana farming provides an alternative source of food, thus availability among the households besides fetching income for the farmers which gives it an added advantage over other cash crops previously grown in the area. These findings are in consistency with those by Bhattacharyya (2008), who reported that majority of farmers embrace diversification of crops as an alternative to better income.

\subsection{Banana Production Trends in Imenti South Sub-County}

Banana production is an all year-round enterprise in the study area while the quantity of banana produced varied each year.

\section{a. Banana Production from the 2000 to 2019 in the Study Area}

Banana is a perennial crop provides steady source of income and food to the family all year round. This has been supported by Kabunga et al., (2011) who cited that in Kenya, banana is almost exclusively grown by every smallholder farmer for home consumption and markets. The results showed that banana acreage and production has been increasing in the period 2000-2019. 


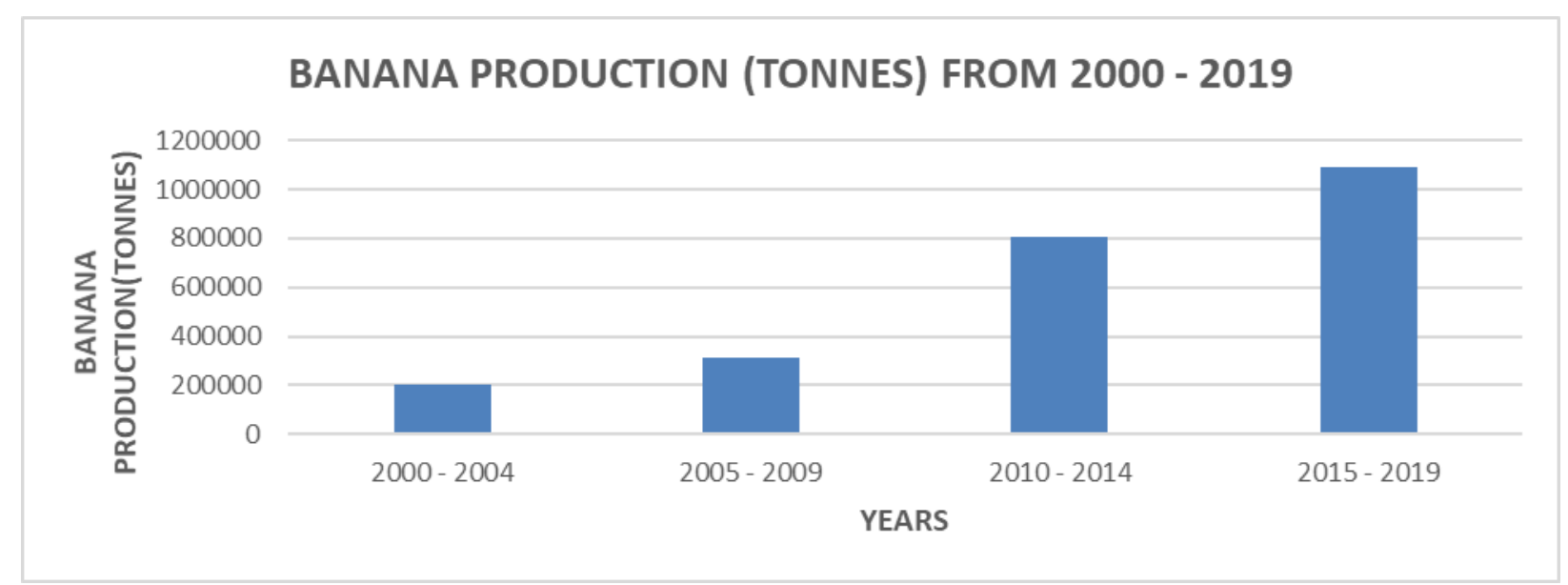

Figure 3. Banana Production in Tonnes (source: Imenti South Agricultural Office)

The study revealed that banana production increased from 205221 tonnes in the year 2000-2004. This increased to 311266 tonnes in between 2005-2009. There was a further increase in volumes to 803338 tonnes in years 2011 and 2014. The volumes were highest in the last 5 years, between 2015 and 2019, which recorded a volume of 1089025 in Imenti South Sub-County. The study results indicated that banana yields and farms have been gradually increasing over the years in the study area. This is in line the GOK (2008) which noted that horticulture farming where banana production falls is among the fastest growing industry within the agricultural sector in Kenya, recording an average growth of between 15\% and 20\% per annum. The findings also agree with those by Koigi, (2013) who reported that banana production in Meru County had increased over the years. The average banana production in the study area increase from the year 2000 to 2005 which was attributed to the increased quality and prices, high market prices, high quality and improved banana husbandry. However there was a drop in production per hectare in year 2006 and 2007 as a result of inadequate water for irrigation. The upward trend was observed between the year 2008 to 2011 due to improved irrigation and prices. The production dropped slightly between 2012 and 2014 due to lack of irrigation water. The production further increased from 2015 to 2019 due to availability of water and high banana prices.

The study further revealed that farmers abandoned low value crops such as coffee, tobacco, maize and cereals to embrace banana farming due to its higher economic returns, source of food for the households and favorable ecological conditions. Banana production was practiced either as mono crop or as mixed farming by planting bananas alongside other cash crops like coffee as the plate (b) below indicates. This practice was common for some due to inadequate land or fear of losing benefits accrued to traditional crops or as an option for increased production. These findings agree with those by Bhattacharyya (2008), who reported that majority of farmers embrace banana crop as an alternative to better income and food for the households. 

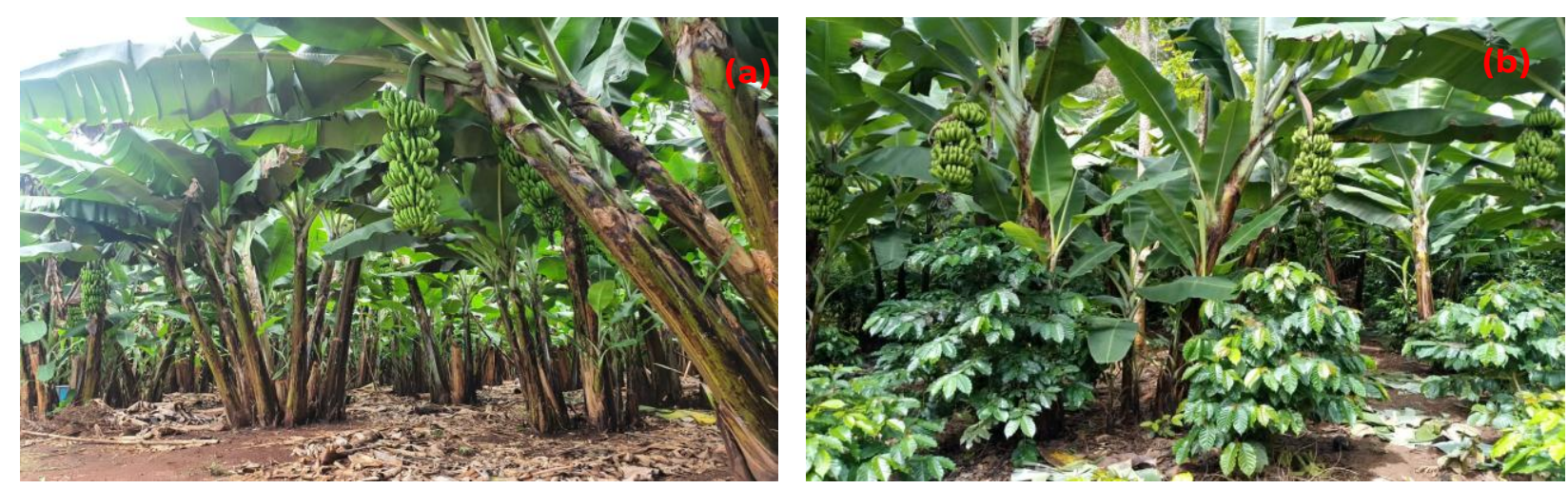

Plate 1. Banana as a mono crop (a) and mixed cropping on the farmer's field (b).

Table 6. Summary of Crop Production in Tonnes by Type of Crop in Imenti South Sub-

\begin{tabular}{llll}
\hline \multicolumn{4}{c}{ county } \\
\hline (I) Type of crop & (J) Type of crop & Mean Difference (I-J) & Sig. \\
\hline Bananas & Maize & $90391.100^{*}$ & .001 \\
Maize & coffee & 45902.600 & .123 \\
& Bananas & $-90391.100^{*}$ & .001 \\
coffee & coffee & -44488.500 & .139 \\
& Bananas & -45902.600 & .123 \\
& Maize & 44488.500 & .139 \\
\hline
\end{tabular}

*Significance is at .005

Further scrutiny of the details in the Tukey post hoc test presented in table 6 showed that banana production was statistically significantly larger than maize production $(p=.001)$. However, banana production was not statistically significant than coffee production $(p=$ .123). Moreover, Maize production and coffee production had no significant difference ( $\mathrm{p}=$ .139). From the data presented therefore, it is clear that production of bananas has been higher than other crops over a period of 20 years in Imenti south sub county.

Further analysis was done to determine whether a relationship existed between land use change in terms of acreage under banana farming and banana production. To achieve this goal, data obtained from Imenti south agricultural office with regard to land utilized for banana production from 2000 to 2019 and banana production in tons per year over the same period was correlated. A Pearson moment correlation coefficient was generated and the results presented in table 7 .

Table 7. Summary of Pearson Moment Correlation between Acreage under Banana Farming and Banana Yield in Tons Per Hectare

\begin{tabular}{llll}
\hline & & Acreage & in \\
& & Hectares & Yield in tons \\
\hline Acreage in Hectares & Pearson Correlation & 1 & $.617^{* *}$ \\
& Sig. (2-tailed) & & .004 \\
\multirow{4}{*}{ Yield in tons } & $\mathrm{N}$ & 20 & 20 \\
& Pearson Correlation & $.617^{* *}$ & 1 \\
& Sig. (2-tailed) & .004 & \\
& $\mathrm{~N}$ & 20 & 20 \\
\hline
\end{tabular}

**. Correlation is significant at the 0.01 level (2-tailed). 
Table 7 shows that, there was a positive and statistically significant relationship ( $\mathrm{r}=$ $.617 ; \mathrm{p}=.004)$ between land under banana farming and banana production. Findings from the ANOVA revealed that there was a significant difference in land use with regard to banana production as compared to land use in other crop faming, as well as a significant difference in banana production as compared to other crops. Further, analysis from Pearson moment correlation revealed a significant relationship between land use change and banana production.

\section{b. Factors for Continued Increase in Banana Production}

The study sought to establish the reasons for continued increase in banana production in the study area. Majority of the respondents (67\%) agreed has ensured food security in their homes. Fifteen percent $(15 \%)$ of respondents changed to banana farming as a result of influence from other farmers while $9 \%$ embraced banana production due climate variability which affected production of previously grown crops. The results showed that traditional farming and crops were sustaining food demands by the households, nec essitating adoption of banana farming for subsistence to supplement families with food stocks with money earned. This result affirms the report by Farmbiz Africa (2019) which indicated that more than 2,200 small scale farmers in Meru County who were previously practicing coffee and miraa production have found a new venture in banana farming in the area.

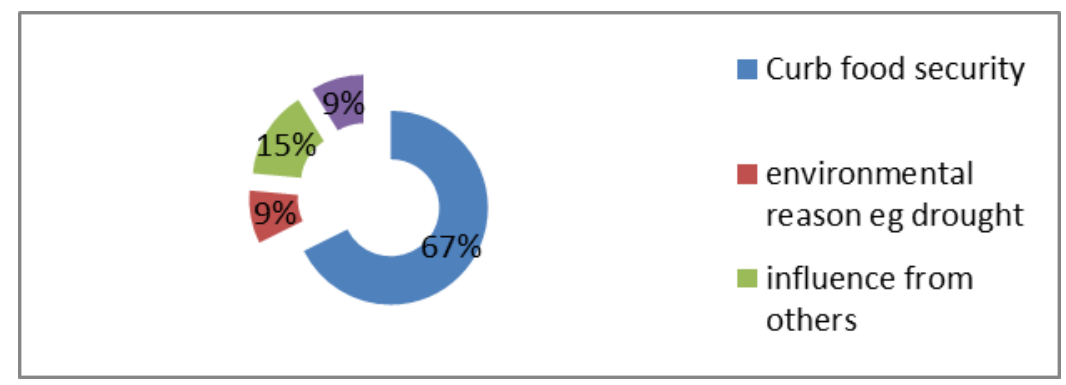

Figure 4. Factors for Continued Increase in Banana Production

\section{Conclusion}

Banana farming has huge potential of benefiting not only producers the smallholder's farmers but other actors. However, several interdependent constraints that amplify each other, hinder the realization of the benefits and hence affecting the banana production negatively. It is therefore important that interventions be made from the County government, national government and other actors in order to comprehensively address the constraints. The acreage under banana production has been increasing in the study region from 2000 to 2019 . This is as a result of increased demand of bananas produce in urban and peri urban area for hotels and also big institutions such as schools and hospitals. This study revealed that banana farming had been adopted by majority of the smallholder farmers, dropping other crops. This was attributed to the fall of coffee price in the world market and high costs of inputs for coffee production. However, the future of banana production in Imenti South Sub-County may not be predicted due to challenges associated inadequate water for irrigation. Farmers are opting to reverse to coffee farming due to new prices and the newly amended Coffee Act which has transformed coffee industry.

\section{Recommendations}

1. Both national and county governments to provide adequate facilities and infrastructure for banana value addition such as processing facilities, marketing of the banana products and kick out brokers and middlemen in the production process to improve benefits associated with banana farming and optimize a return that benefits the farmer. 
2. Institutionalize farmers' support systems and structures such as well managed, equipped institutions to provide technical and material support (i.e. supply of irrigation water, good market price regulation and farmer training) to the farmers at the local level to help cushion the banana farmer.

3. The county governments should utilize these programs to address the issues raised by the banana farmers so as to improve production and the quality of the bananas in the county.

\section{References}

Abere,.B..O. and Waithaka, E. H. (2014)Land Use Land Cover Changes and Implications for Food Production: A Case Study of Keumbu Region, Kisii County, Kenya. International Journal of Science and Research (IJSR)

Bhattacharyya R. (2008). Crop Diversification: A search for alternative income of the farmers in the State of West Bengal in India. Available at: http://kastoria.teikoz.gr/icoaez/wordpress/wpcontent/uploads/articles/2011/10/012 2008.df

Cresswell, J. (2012). Qualitative inquiry and research design: Choosing among the five traditions (3rdedn.). Thousand Oaks, CA:Sage.

Cresswell, J. \& Miller, D. (2000).Determining Validity in Qualitative Inquiry.Theory into Practice. 39.3.pp.124-30

CyriaqueHakizimana, Paul Goldsmith, AbdiAralleNunow, AdanoWarioRoba\& Jane KathureBiashara (2017) Land and agricultural commercialization in Meru County, Kenya: evidence from three models, The Journal of Peasant Studies, 44:3, 555-573

FAO. (2018a). Banana Market Review 2017. www.fao.org/fileadmin/templates/est/COMM_MARKETS_MONITORING/Banana s/Documents/web_Banana_Review_2018_Final_DV.pdf

FAO. (2018b). Banana Statistical Compendium 2017. www.fao.org/fileadmin/templates/est/COMM_MARKETS_MONITORING/Banana s/Documents/Banana_Statistical_Compendium_2017.pdf

Farmbiz Africa (2019) Ready Market Excites over 2,200 Meru Farmers to Grow Bananas. Markets.HITS 2268.Meru. Kenya

GOK (2019) Meru County: 2019 Long Rains Food and Nutrition Security Assessment Report - July 2019.NDMA. Nairobi.

GOK (2015a). Meru County statistical abstract, KNBS, Nairobi

GOK (2015c) Kenya Coffee (General) regulations, 2015, GOK, Nairobi

GOK, (2014) Agricultural Sector Development Support Program. Government of Kenya, Ministry of Agriculture Livestock and Fisheries.

GOK, (2012), Ministry of Agriculture Validated Report 2012, Karuri Ventures, Nairobi

GOK, (2011), Ministry of Agriculture Validated Report 2011, Karuri Ventures, Nairobi

GOK, (2009). Kenya Population and Housing Census (KPHC). Government of Kenya, Kenya National Bureau of Statistics, Nairobi, Kenya.

GOK, (2008), Domestic Horticulture Marketing and Market infrastructures in Kenya, Nairobi Imaging Centre, Nairobi

GOK, (2002), Horticulture Division Annual Report, Government Press Nairobi

Kabunga, S., Dubois, T., Qaim, M., (2011), Impact of Tissue Culture Banana Technology on Farm Household Income and Food Security in Kenya, Courant Research Centre: Poverty, Equity and Growth - Discussion Papers, No. 89, Courant Research Centre Poverty, Equity and Growth, Göttingen.

Karanja, M. and Nyoro J., (2002), Coffee prices and regulation and their impact on livelihoods of rural community in Kenya. Tegemeo institute of agricultural policy and development, Egerton University. 
Koigi B. (2013). Meru floors Kisii to lead in Banana production. Journal of Tropical Agriculture, Food, Environment and Extension, 4: 84-89

Karienye J and Kamiri H. (2020). Trends of Banana Production among Smallholders' Farmers Due to Rainfall and Temperature variations in Mount Kenya Region, Kenya. Budapest International Research in Exact Sciences (Bir Ex) Journal Volume 2. Page:213-227

Krejcie, R.V \& Morgan D.V (1970) "Determining Sample Size for Research Activities" Educational and Psychological Measurement, 30, pp. 607-610

Mbaka, J., Mwangi, M., and Mwangi, N. (2008). Banana farming as a business: The role of tissue cultured planting materials in Kenya. Journal of Applied Biosciences, 9(1):354361. Mekuria W. (2018) The link between agricultural production and population dynamics in Ethiopia: a review. Adv Plants Agric Res.;8(4):348-353.

Meru County Integrated Development Plan, 2018-2022, Meru County Government, Meru, Kenya

Ministry of Agriculture, Livestock and Fisheries, (MoALF), (2017) Agriculture Joint Sector Review Assessment for Kenya, Nov 201. Nairobi

MoA (2013) Report on: Food and Crop Situation, Imenti South sub-County, MeruCounty, Kenya.

Morton, J. (1987), Banana. In: Fruits of warm climates. Julia F. Morton, p. 29-46 Miami, FL.

Morgan, D.L., (1988) Focus Groups as Qualitative Research. Sage Publications, Newbury Park, CA.

Monish Jose \& Martina Padmanabhan(2016)Dynamics of agricultural land use change in Kerala: a policy and social-ecological perspective,International Journal of Agricultural Sustainability, 14:3,307-324

Mugenda, O. \&Mugenda, A. (2003).Research Methods; Quantitative and Qualitative Approaches.Nairobi: Arts Press.

Mwendia, A.S (2019) An Investigation of the Drivers of Diversification to Banana Farming Among Households in Meru County, Kenya. Unpublished Masters of Arts In Geography. Kenyatta University, Nairobi

SPSS, I. (2012). IBM SPSS statistics version 21. Boston, Mass: International Business Machines Corp, 126.

Splisbury, J., Jagwe, J., Wanda, K., \& Nkuba, J. (2003). Evaluating the Marketing Opportunities for Banana Growing Countries of ASARECA. Regional Report from Kenya, Rwanda, Tanzania and Uganda.

Suryani, M. \& Rony, S. (2020). The Effect of Government Expenditures, Domestic Invesment, Foreign Invesment to the Economic Growth of Primary Sector in Central Kalimantan, Budapest International Research and Critics Institute-Journal (BIRCIJournal). Page: 1692-1703

UNEP, (2011) Towards a Green Economy: Pathway to Sustainable Development and Poverty Eradication, United Nations Environment Programme. www.unep.org/green economy.

USAID, (2013), Uganda Climate Change Vulnerability Assessment Report. USAID African and Latin American Resilience to Climate Change.

Von Ketteler, Lorenza. (2018) Factors influencing farmer's decision-making and resilience.The case of banana production in Amubri, Costa Rica.Master thesis in Sustainable Development at Uppsala University, No. 2018/23, pp. 63, 30 ECTS/hp.

Wambugu F.M., and Kiome R.M., (2001) "The benefits of bio-technology for Small Scale Banana Producers in Kenya". ISAAA, International Service for the Acquisition of Agribiotechnology Applications, Ithaca, New York.

Yusin, K and Diana, S (2020). The Local Wisdom of Angkola in Efforts to Love the Environment Budapest International Research and Critics Institute-Journal (BIRCIJournal). Page: 2053-2063 